\title{
Coagulation efficiency and its determinant factors: A case study for Manchega ewe milk in the region of Castilla-La Mancha, Spain
}

\author{
J. Caballero-Villalobos, ${ }^{* 1}$ J. M. Perea, ${ }^{*}$ E. Angón, ${ }^{*}$ R. Arias, † and A. Garzón* \\ *Departamento de Producción Animal, Universidad de Córdoba, Córdoba 14071, Spain \\ †Centro Regional de Selección y Reproducción Animal de Castilla-La Mancha, Valdepeñas, Ciudad Real 13300, Spain
}

\begin{abstract}
Milk coagulation, especially in small ruminant species, is often hard to evaluate, as coagulation traits are normally considered individually and several factors related to udder health might distort yield calculation. Due to the lack of studies about these factors, our objective was to determine milk coagulation efficiency (CE) and its determinants using a deterministic technical efficiency approach, an ordinary least square regression model, and ANOVA. Milk from 300 Manchega ewes was collected and analyzed for composition, milk coagulation properties, and hygienic quality. The study results indicate that the estimated $\mathrm{CE}$ in Manchega ewes was 0.69 , implying an important proportion of the animals produce poorly coagulating milk. The results of the ordinary least square regression model and ANOVA revealed that the main factor causing inefficiency was the initial $\mathrm{pH}$ of milk. Crude protein, casein and plasmin activity had moderate effects on $\mathrm{CE}$, and, finally, other factors such as freezing point depression, somatic cell count, colony-forming units, and fat concentration had minor effects.
\end{abstract}

Key words: sheep milk, coagulation efficiency, Manchega, hygienic quality

\section{INTRODUCTION}

In Spain, as in many Mediterranean countries, almost the entire production of sheep milk is used for cheesemaking, whether in pure form or mixed with goat or bovine milk (Jaramillo et al., 2008). Cheese production represents a major component of the European ovine industry, and in the last few years this has been strengthened by the emergence of Protected Designation of Origin and Protected Geographical Indications, which assures control of production and processing fac-

Received September 25, 2017.

Accepted January 14, 2018.

${ }^{1}$ Corresponding author: v22cavij@uco.es tors and guarantees consumers of high-quality products (Bittante et al., 2012).

Manchega is the most common dairy sheep breed in Spain, with approximately 650,000 ewes in production (Morantes et al., 2017). Farming systems for this breed are based on small family farms and mainly characterized by family labor and grazing, wherein crops and livestock are developed in an integrated manner. This so-called mixed system is semiextensive and based on continuous pasturing during the whole year to maximize use of natural resources (Rivas et al., 2015). Milk from this breed is used to make Manchego cheese, a cured hard cheese manufactured exclusively in the region of Castilla-La Mancha. It is the best-selling cheese variety in Spain and since 1996 has been protected by a Protected Designation of Origin that guarantees quality (Arias et al., 2016).

Due to this important cheese production, ewe and milk selection criteria have always focused on obtaining high yields from milk coagulation (Sturaro et al., 2014). However, several factors, such as udder damage and the worsening of sanitary quality of milk, are known to increase moisture in the curd, so higher curd yields than expected are often measured (Albenzio and Santillo, 2011).

On the other hand, milk coagulation properties are strongly affected by breed and milk composition and hygiene, which can influence gelation, curd-firming, and syneresis processes. On this basis, Casper et al. (1998) reported a higher fat and total protein content in whey from the manufacture of Manchego cheese compared with the composition of whey from other specialty cheeses. Furthermore, coagulation traits in sheep milk seem to differ from the results obtained in bovine milk, which requires further exploration of milk coagulation determinants in small ruminants (Pazzola et al., 2014).

So far, rennet coagulation time (RCT) and curd firmness $\left(\mathbf{A}_{\mathbf{3 0}}\right)$ have usually been considered individually when studying milk coagulation. However, the relationship between these 2 variables is an indicator of efficiency in the coagulation process and, consequently, could be optimized through the methodological frame- 
work of technical efficiency (Timmer, 1971). Using this procedure, the most efficient coagulation in a set of experimental units can be used as a leading reference to measure the relative efficiency of each unit and to determine the causes of inefficiency. This approach, commonly used in economic sciences, has proved to be useful to evaluate farming systems (Iliyasu and Mohamed, 2016). Therefore, its application to a biological field such as dairy production could lead to a better knowledge to improve sustainability in ewe farms. Based on this background, the objective of our study was to evaluate coagulation efficiency of Manchega ewe milk and to determine the factors responsible for inefficiencies.

\section{MATERIALS AND METHODS}

\section{Data Set and Collection of Milk Samples}

The farm La Nava del Conejo (Valdepeñas, Spain) is registered in the National Association of Manchega Sheep Breeders (AGRAMA) and hosts a benchmark flock for the genetic selection scheme of this breed. Milk from 300 Manchega ewes from this farm was collected and analyzed for milk composition, milk coagulation properties (MCP), SCC, bacterial count, and plasmin activity (PL). All animals included in our study were in the same lactation cycle and milked twice per day. Milk samples were collected during the morning milking and each analysis was performed twice in the laboratory.

\section{Laboratory Analysis}

After sample collection, milk was stored at $4^{\circ} \mathrm{C}$ for $5 \mathrm{~h}$ until analysis. Major milk components (fat, CP, lactose, TS, casein, and urea), freezing point depression (FPD), and colony-forming units were directly measured using a Milko-Scan FT-6000 (Foss Electric, Hillerød, Denmark). To determine ash, milk samples $(10 \mathrm{~mL})$ were dried in a laboratory oven for $24 \mathrm{~h}$ and left in a muffle furnace for $2 \mathrm{~h}$ at $550^{\circ} \mathrm{C}$ (Casado Cimiano, 1991). Samples were stored in a desiccator with silica gel for 30 to $45 \mathrm{~min}$, and weighed to calculate ash content. Somatic cell count was measured using a Fossomatic FC (Foss Electric) and expressed as cells per milliliter, of which logarithmic transformation was applied to normalize the distribution (Ali and Shook, 1980). Milk coagulation properties were monitored at $32^{\circ} \mathrm{C}$ using a Formagraph viscometer (Foss Electric) following the method developed by McMahon and Brown (1982) with modifications described by Caballero-Villalobos et al. (2015). This method is based on the oscillatory motion of circular pendula immersed in milk during coagulation; this information is transferred to a computer, where the result of the pendulum movements is represented in a diagram. The testing time of the analysis was set up at 60 min and milk coagulation was initiated by the addition of $50 \mu \mathrm{L}$ of a $4 \%$ singlestrength liquid animal rennet dilution. The measured parameters included RCT (defined as the time elapsed until the formation of the curd) and $\mathrm{A}_{30}$ (which represents the width of the coagulation diagram at 30 min). Plasmin activity was determined according to the method described by Richardson and Pierce (1981) using the peptide $N$-succinyl-L-alanyl-L-phenylalanyl-Llysyl-7-amino-4-methyl coumarin. Plasmin cleaves this peptide and releases 7-amino-4-methyl coumarin, which can be quantified spectrofluorometrically. Milk $(3 \mathrm{~mL})$ was added to $1 \mathrm{~mL}$ of $0.4 \mathrm{M}$ trisodium citrate and centrifuged $\left(29,000 \times g, 20 \mathrm{~min}, 4^{\circ} \mathrm{C}\right)$. The supernatant was recovered and filtered through Whatman No. 1 filter paper (GE Healthcare, Chicago, IL) and $50 \mu \mathrm{L}$ of filtrate were added to $825 \mu \mathrm{L}$ of $50 \mathrm{~m} M$ Tris- $\mathrm{HCl}$ buffer $\mathrm{pH} 7.5$ and incubated for 5 min at room temperature. The reaction was initiated by adding to the mixture $225 \mu \mathrm{L}$ substrate $(5 \mathrm{mg}$ of coumarin peptide in 1.33 $\mathrm{mL}$ of dimethyl sulfoxide and $5.33 \mathrm{~mL}$ of $50 \mathrm{~m} M$ Tris$\mathrm{HCl}$ buffer, $\mathrm{pH}$ 7.5), and fluorescence intensity (380 nm excitation, $460 \mathrm{~nm}$ emission) was measured at 5-min intervals over a period of $35 \mathrm{~min}$. Plasmin activity was determined from the linear part of the fluorescence emission versus time curve. One unit of plasmin activity was defined as the activity necessary to release 1 nmol of 7-amino-4-methyl coumarin/min per milliliter of milk under the conditions of the assay.

\section{Data Description}

Modeling Coagulation Performance of Manchega Milk. The relationship between $\mathrm{A}_{30}$ and $\mathrm{RCT}$ was modeled using least square simple regression, taking curd firmness as dependent variable $(Y)$ and RCT as the independent variable $(X)$. Twenty-three alternative models were built and evaluated. The adjustment of the model was determined through the adjusted coefficient of determination and contrasted using ANOVA. Heteroscedasticity was evaluated using the White test, and the Chow test was used to determine the stability of the regression coefficients. The Kolmogorov-Smirnov test was used to verify the normality in residual distribution and the Durbin-Watson test was used to detect the absence of autocorrelation in the residuals (ToroMújica et al., 2011; Angón et al., 2013). Among the models that fulfilled the previously established conditions, the one with the best adjustment was (Table 1)

$$
Y_{i}=\beta_{0}+\beta_{1} X_{1}^{2}+\mu_{i},
$$


Table 1. Adjusted regression model between observed values of curd firmness $(Y)$ and rennet coagulation time $(X)$ of Manchega sheep milk ${ }^{1}$

\begin{tabular}{lcccc}
\hline Parameter & Coefficient & SE & Student's $t$-test & $P$-value \\
\hline Intercept $\left(\beta_{0}\right)$ & 50.585 & 1.036 & 48.817 & 0.000 \\
Slope $\left(\beta_{1}\right)$ & -0.0426 & 0.002 & -17.650 & 0.000 \\
White test & & & & 0.123 \\
Chow test & & & & 0.342 \\
Kolmogorov-Smirnov test & & & & 0.598 \\
Durbin-Watson test & & & 0.000 \\
ANOVA & 64.224 & & & \\
$\mathrm{R}^{2}$ & & & \\
\hline
\end{tabular}

${ }^{1}$ White test was used to evaluate heteroscedasticity; Chow test was used to determine the stability of the regression coefficients; Kolmogorov-Smirnov test was used to verify normality; Durbin-Watson test was used to detect the absence of autocorrelation in the residuals from a regression analysis.

where $Y_{i}$ denotes $\mathrm{A}_{30}, X_{i}$ denotes $\mathrm{RCT}, \beta_{0}$ denotes the intercept, $\beta_{1}$ denotes the slope, and $\mu_{i}$ denotes the term that includes the model residues.

Coagulation Efficiency of Manchega milk. Once the model had been built, and following Greene (1980), the deterministic frontier function was computed with the corrected ordinary least squares method. By adding the maximum positive residual to the intercept, the estimated function was displaced, thereby obtaining the frontier function of coagulation (Pérez et al., 2007; Toro-Mújica et al., 2011). The frontier function of coagulation thus allows the maximum curd firmness to be obtained from a given RCT. The relationship between the observed and estimated $\mathrm{A}_{30}$ of each milk sample enabled the calculation of an efficiency score according to their coagulation performance. Therefore, coagulation efficiency $(\mathbf{C E})$ indexes were calculated using the method of Timmer (1971), expressed as

$$
C E_{i}=1-\left(\frac{Y_{i}-Y_{i}^{\prime}}{Y_{i}^{\prime}}\right),
$$

where $C E_{i}$ denotes the coagulation efficiency index, $Y_{i}$ denotes the observed curd firmness, and $Y_{i}^{\prime}$ denotes the curd firmness predicted by the frontier function.

Ordinary Least Squares Regression Model. Although most previous studies used the Tobit regression model when investigating the determinants of technical inefficiency (Cinemre et al., 2006; Kaliba and Engle, 2006; Alam, 2011), McDonald (2009) argued that the use of Tobit regression model is inappropriate in this situation. Coagulation efficiency scores are fractional data and not generated by a censoring process; thus, the use of ordinary least squares (OLS) regression modeling was the most appropriate technique. This argument was supported by Banker and Natarajan (2008) as well as Iliyasu and Mohamed (2016); therefore, the OLS method was employed to investigate the determinants of CE among the milk samples. Following Iliyasu and Mohamed (2016), the model can be expressed as

$$
C E=\beta_{0}=\sum_{i=1}^{n} \beta_{i} z_{i}+\delta,
$$

where $C E$ denotes the measure of coagulation efficiency and $\beta_{i}$ denote unknown parameters to be estimated; $z_{i}$ are the sanitary or compositional variables defined in Table 2, whereas $\delta$ is the error term. To avoid multicollinearity between the regressors in the model, a correlation matrix was constructed. Correlated variables were eliminated on the basis of the square root of the determination coefficient and $F$ statistics. Once the model had been defined, the degree of collinearity was analyzed using the simple correlation coefficient. Coefficients of determination obtained in the model were compared with all and each of the correlation coefficients between each pair of independent variables. A serious problem of multicollinearity was deemed to exist if any of the partial correlation coefficients exceeded the multiple correlation coefficient (Pulido and Pérez, 2001; Toro-Mújica et al., 2011). Once the model had been obtained, normal distribution of residuals was confirmed using the Kolmogorov-Smirnov test. Heteroscedasticity was evaluated using the White test, and the Chow test was used to determine the stability of regression coefficients (García et al., 2007). Zootechnical values (parity and udder damage) were categorical and, therefore, not included in the OLS model. To evaluate their effect over coagulation efficiency, Student's $t$-test was performed.

$\boldsymbol{A N O V A}$. Milk samples were categorized in terms of $\mathrm{CE}$ in 3 levels (high, medium, and low). The limits of the medium category were set at quartiles 2 and 3. In addition, a fourth group of noncoagulating milk samples (NCM) was included $(\mathrm{n}=26)$. Subsequently, ANOVA was used to identify variables giving rise to 
Table 2. Description of variables used to estimate efficiency scores and inefficiency determinants in Manchega sheep milk $(\mathrm{n}=274)$

\begin{tabular}{|c|c|c|c|c|}
\hline Variable & Description & Unit & Mean & $\mathrm{SD}$ \\
\hline $\mathrm{A}_{30}(Y)$ & Curd firmness at $30 \mathrm{~min}$ & $\mathrm{~mm}$ & 34.08 & 11.77 \\
\hline $\operatorname{RCT}(X)$ & Rennet coagulation time & $\min$ & 18.90 & 5.40 \\
\hline Parity & Dichotomic & $0=$ primiparous, $1=$ otherwise & - & - \\
\hline Udder damage & Dichotomic & $0=$ no previous damage, $1=$ otherwise & - & - \\
\hline \multicolumn{5}{|l|}{ Milk composition } \\
\hline $\mathrm{TS}\left(\mathrm{Z}_{3}\right)$ & TS content & $\%$ & 18.48 & 2.76 \\
\hline Lactose $\left(\mathrm{Z}_{4}\right)$ & Lactose content & $\%$ & 4.79 & 0.55 \\
\hline Casein $\left(\mathrm{Z}_{5}\right)$ & Casein content & $\%$ & 4.80 & 0.47 \\
\hline $\operatorname{Ash}\left(Z_{6}\right)$ & Ash content & $\%$ & 0.079 & 0.007 \\
\hline Urea $\left(\mathrm{Z}_{7}\right)$ & Milk urea concentration & $\mathrm{mg} / \mathrm{L}$ & 406.60 & 102.25 \\
\hline \multicolumn{5}{|l|}{ Sanitary factor } \\
\hline $\mathrm{cfu}\left(\mathrm{Z}_{8}\right)$ & cfu & $\mathrm{cfu} / \mathrm{mL}$ & 17.12 & 12.17 \\
\hline
\end{tabular}

differences in coagulation efficiency. Following Angón et al. (2013), a simple model with fixed factor was used:

$$
z_{i}=\mu+\alpha_{i}+\delta_{i}
$$

where $z_{i}$ is each observation of the variable $Z_{i}$ defined in Table $2, \mu$ is the average of the population, $\alpha_{i}$ is the effect of the coagulation efficiency level, and $\delta_{i}$ is the random error related to the $z_{i}$ observation. The Student-Newman-Keuls test test was used to determine the existence of significant differences between groups. Data were analyzed using the statistical software SPSS for Windows (v.15.0, SPSS Inc., Chicago, IL).

\section{RESULTS AND DISCUSSION}

The average $\mathrm{CE}$ in the studied population was estimated at 0.69 , with threshold values of 0.33 (minimum) and 1.00 (maximum). Milk samples did not coagulate over a 60 -min period under the minimum $\mathrm{CE}$ values. Figure 1 shows the distribution of the observed values of $\mathrm{A}_{30}$ and $\mathrm{RCT}$ of Manchega sheep. Figure 2 represents the frequency distribution of $\mathrm{CE}$ in Manchega ewes. The majority of ewes produce milk with efficiency scores within the ranges 0.557 to $0.69(28.7 \%)$ and 0.69 to $0.823(29.9 \%)$. Nevertheless, a significant number of animals still produce milk with coagulation efficiencies below 0.50 (17.73\%). This implies that an important proportion of the studied animals produce poorly coagulating milk, which is reflected in low cheese yields, probably due to an increase in the amount of proteolytic activity and a leakage of fat and caseins into whey (Albenzio et al., 2009; Caballero-Villalobos et al., 2017).
Table 3 displays values resulting from the OLS regression analysis, as well as the t-tests performed on categorical factors (parity and health of the udder) in milk from Manchega ewes. To determine if OLS analysis was applicable, data were first tested to check if variables were normally distributed, of which the Kolmogorov-Smirnov test proved the residuals adjusted to a Gaussian distribution $(P=0.598)$. Furthermore, the White test $(P=0.123)$ showed no heteroscedasticity, therefore data were considered suitable for OLS analysis. Fat, casein, and FPD (positive), together with colony-forming units, $\mathrm{pH}$, and $\mathrm{PL}$ (negative) were the most important determinants of coagulation efficiency in this breed. In addition, $t$-tests revealed that both categorical variables were also determinants of efficiency: having a positive (parity) and a negative effect (health of the udder) on coagulation. Given that the $\mathrm{pH}$ of milk can be modified by the addition of some compounds (Caballero-Villalobos et al., 2015), additional OLS analyses were also performed to check possible changes in the response of other variables. First, not including the variable $\mathrm{pH}$; second, by removing from the analysis only those samples with a lower $\mathrm{pH}$ than the minimum required to obtain an industrially acceptable coagulation, considering a threshold $\mathrm{pH}$ value of 6.8 (Lucey and Fox 1992; Bencini 2002). However, in both cases, OLS showed no differences in either the sign or the coefficient of the variables included in the model.

Table 4 shows the results from ANOVA between 3 levels of coagulation efficiency (low, medium, and high) and NCM. The variables that significantly affected CE levels were $\mathrm{CP}$, casein, lactose, colony-forming units, $\mathrm{SCC}, \mathrm{pH}, \mathrm{FPD}$ and PL. Six of these 8 variables dis- 


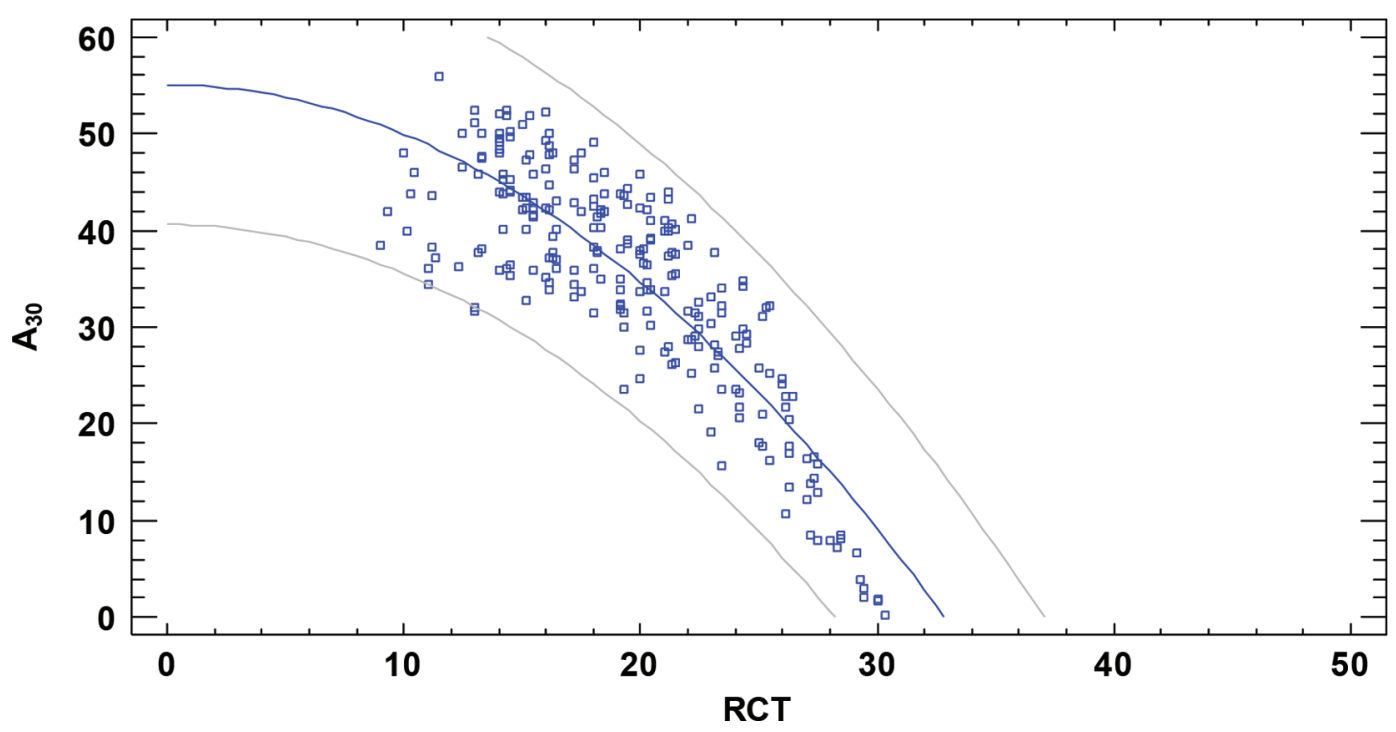

Figure 1. Distribution of the observed values of curd firmness $\left(\mathrm{A}_{30}\right)$ and rennet coagulation time (RCT) of Manchega sheep. The shown regression curve represents the estimations of $\mathrm{A}_{30}( \pm 95 \% \mathrm{CI})$ from the best fitting regression between $\mathrm{A}_{30}$ and $\mathrm{RCT}\left(\mathrm{A}_{30}=50.585-0.0426 \times\right.$ $\left.\mathrm{RCT}^{2}\right)$. Color version available online.

criminated between samples that coagulated and NCM: lactose and FPD (positive effect) and colony-forming units, $\mathrm{SCC}, \mathrm{pH}$, and PL (negative effect). In addition, 4 of the 8 variables established differences between levels of efficiency, having a positive ( $\mathrm{CP}$ and casein) or a negative effect ( $\mathrm{pH}$ and $\mathrm{PL}$ ).

Joint analysis of OLS and ANOVA revealed that, in milks that did coagulate under laboratory conditions, $\mathrm{CE}$ mostly depended on $\mathrm{pH}$, as a higher $\mathrm{pH}$ has a negative effect on MCP. Significant differences were seen for $\mathrm{pH}$ between all $\mathrm{CE}$ groups, including NCM (with an average $\mathrm{pH}$ value of 6.99). The most efficient samples presented a $\mathrm{pH}$ close to 6.5 , in agreement with previously published results (Caballero-Villalobos et al.,

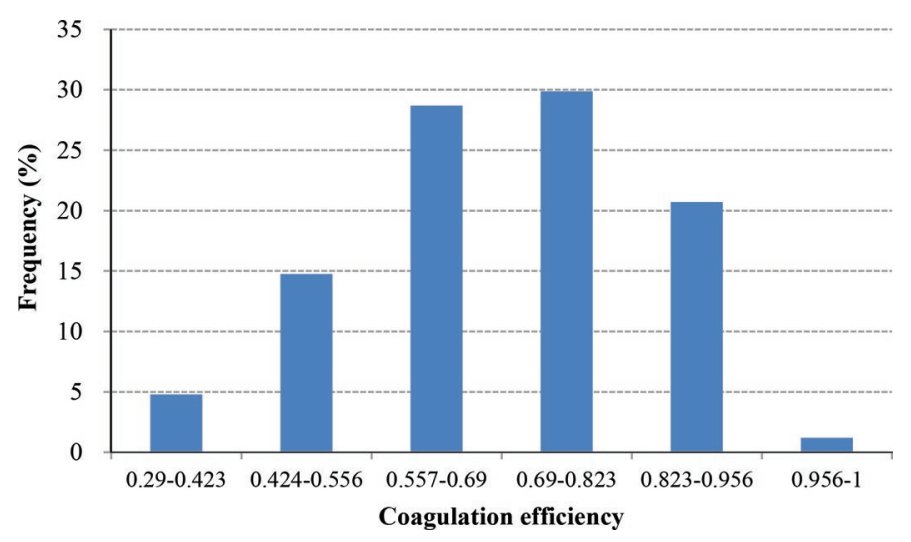

Figure 2. Frequency distribution of coagulation efficiency in Manchega sheep $(\mathrm{n}=274)$. Color version available online.
$2015)$. Only $50 \%$ of the samples within a $\mathrm{pH}$ range of 6.8 to 7.0 coagulated after 60 min, and samples with $\mathrm{pH}$ values higher than 7.0 did not form a curd under the conditions of the analysis.

Of secondary importance, protein also had a notable effect on $\mathrm{CE}$, of which the effect of protein on MCP has been thoroughly described by Bittante et al. (2012) and Logan et al. (2014). In the present study, both $\mathrm{CP}$ and casein were found in significantly greater concentrations in high-CE milk. However, protein and casein in NCM presented intermediate values and did not seem to differ from samples that did coagulate. Medium- and high-efficiency samples presented similar values for plasmin activity (0.865 and 0.899 units $/ \mathrm{mL}$ ), being significantly lower than low-efficiency milk (1.018 units/mL). In NCM, PL was much higher (2.910 units/ $\mathrm{mL}$ ), of which a relation between PL and proteolysis in milk has been extensively reported (Ismail and Nielsen, 2010; Moatsou, 2010). Therefore, proteolytic activity could explain the ambiguous values of the protein fraction in NCM, as plasmin would cleave $\beta-\mathrm{CN}$, thus reducing the amount of protein incorporated in the gel during rennet coagulation (Bastian and Brown, 1996; Theodorou et al., 2007).

Other variables with a minor influence on $\mathrm{CE}$ were SCC, colony-forming units, FPD, and fat concentration. Somatic cell count has been described to greatly affect sheep and goat milk rennet coagulation (Leitner et al., 2008); however, in the present study, differences in SCC were only seen in NCM, whereas levels remained fairly constant between the 3 levels of efficiency, in agreement 
Table 3. Determinants of coagulation efficiency in Manchega sheep $(\mathrm{n}=274)$

\begin{tabular}{|c|c|c|c|c|}
\hline Variable & Coefficient & $\mathrm{SE}$ & Student's $t$-test & $P$-value \\
\hline \multicolumn{5}{|l|}{ Zootechnical factor } \\
\hline Parity & - & - & -2.84 & 0.005 \\
\hline Udder damage & - & - & -2.25 & 0.026 \\
\hline \multicolumn{5}{|l|}{ Milk composition } \\
\hline Fat & 0.126 & 0.048 & 2.61 & 0.009 \\
\hline $\mathrm{CP}$ & - & - & - & - \\
\hline TS & - & - & - & - \\
\hline Lactose & - & - & - & - \\
\hline Casein & 0.162 & 0.063 & 2.54 & 0.012 \\
\hline Ash & - & - & - & - \\
\hline Urea & - & - & - & - \\
\hline \multicolumn{5}{|l|}{ Sanitary factor } \\
\hline Microbial count & -0.0001 & 0.0000 & -2.19 & 0.029 \\
\hline SCC & - & - & - & - \\
\hline $\mathrm{pH}$ & -0.227 & 0.064 & -3.52 & 0.000 \\
\hline Freezing point depression & 0.005 & 0.001 & 4.50 & 0.000 \\
\hline Plasmin activity & -0.039 & 0.014 & -2.78 & 0.006 \\
\hline
\end{tabular}

with Koutsouli et al. (2015). This could be explained by previous results from Pirisi et al. (2000), who found that in milk samples with a $\mathrm{pH}$ close or standardized to 6.5, the effects of somatic cells on MCP were negligible. In addition, the fact that SCC did not vary between efficiency, unlike plasmin, suggests that SCC is not the only variable for predicting enzymatic evolution in milk, as PL is affected by a complex network of molecular interactions between enzyme activators and inhibitors (Albenzio et al., 2009). High colony-forming units clearly were related to NCM, but bacterial counts did not vary between the 3 levels of CE. This is in agreement with other results obtained from experiments performed on cow (De Marchi et al., 2007) and goat milk (Pazzola et al., 2012), where no correlation was found between colony-forming units and milk coagulation traits $\left(\mathrm{RCT}, \mathrm{A}_{30}\right)$. Increases in FDP in ewe milk have been associated with a deterioration of MCP (Manca et al., 2016), as reflected in the present results. However, FDP has been proven to be normally constant due to osmotic regulation involving lactose and chloride (Raynal-Ljutovac et al., 2005). Lastly, fat concentration had a positive effect on CE and, although the effect of fat on MCP is not as evident as that of casein, recent studies have suggested that fat globule size may have an influence on viscosity of milk, which should be considered in further experiments (Logan et al., 2014).

Categorical variables (parity and udder health) also have an influence on CE. Results indicate that in milk from primiparous ewes, CE was significantly lower than in milk from multiparous (61.11 vs. $68.17 \%$ ). Although some authors did not find an effect of parity on MCP (Jaramillo et al., 2008), others have described an increase in curd firmness, which would improve CE

Table 4. Determinants of coagulation levels in Manchega sheep $(\mathrm{n}=300)$

\begin{tabular}{|c|c|c|c|c|c|c|}
\hline Variable & $\begin{array}{l}\text { Noncoagulating } \\
\text { milk }\end{array}$ & Low CE & Medium CE & High CE & SEM & $P$-value \\
\hline Coagulation efficiency (CE) & - & $0.489^{\mathrm{a}}$ & $0.701^{\mathrm{b}}$ & $0.863^{\mathrm{c}}$ & 0.009 & 0.000 \\
\hline \multicolumn{7}{|l|}{ Milk composition } \\
\hline $\mathrm{CP}(\%)$ & $6.04^{\mathrm{ab}}$ & $5.81^{\mathrm{a}}$ & $5.80^{\mathrm{a}}$ & $6.02^{\mathrm{b}}$ & 0.05 & 0.032 \\
\hline TS $(\%)$ & 18.70 & 18.45 & 18.27 & 18.91 & 0.21 & 0.442 \\
\hline Lactose $(\%)$ & $4.46^{\mathrm{a}}$ & $4.77^{\mathrm{b}}$ & $4.83^{\mathrm{b}}$ & $4.73^{\mathrm{b}}$ & 0.04 & 0.020 \\
\hline \multicolumn{7}{|l|}{ Sanitary factor } \\
\hline Microbial count (cfu/mL) & $45.08^{\mathrm{b}}$ & $17.61^{\mathrm{a}}$ & $16.45^{\mathrm{a}}$ & $17.97^{\mathrm{a}}$ & 2.34 & 0.010 \\
\hline $\mathrm{SCC}\left(\times 10^{3}\right.$ cells $\left./ \mathrm{mL}\right)$ & $2.26^{\mathrm{b}}$ & $1.93^{\mathrm{a}}$ & $1.82^{\mathrm{a}}$ & $1.90^{\mathrm{a}}$ & 0.03 & 0.002 \\
\hline $\mathrm{pH}\left(-\log \left[\mathrm{H}^{+}\right]\right)$ & $6.99^{\mathrm{d}}$ & $6.72^{\mathrm{c}}$ & $6.65^{\mathrm{b}}$ & $6.62^{\mathrm{a}}$ & 0.01 & 0.000 \\
\hline Freezing point depression $\left(\mathrm{m}^{\circ} \mathrm{C}\right)$ & $580.4^{\mathrm{b}}$ & $588.4^{\mathrm{a}}$ & $589.2^{\mathrm{a}}$ & $588.8^{\mathrm{a}}$ & 0.66 & 0.004 \\
\hline Plasmin activity (units/mL) & $2.910^{\mathrm{c}}$ & $1.018^{\mathrm{b}}$ & $0.865^{\mathrm{a}}$ & $0.899^{\mathrm{a}}$ & 0.08 & 0.000 \\
\hline
\end{tabular}

\footnotetext{
${ }^{\mathrm{a}-\mathrm{c}}$ Means without a common superscript are statistically different.
} 
(Albenzio et al., 2009; Abilleira et al., 2010). Sevi et al. (2004) reported that the increase of body mass in ewes with more lactations probably involves a higher availability of body reserves used in the synthesis of milk components. This could explain the results obtained in the present study, as fat and protein contents in multiparous ewes (7.14 and 5.99\%, respectively) are significantly higher than in primiparous $(6.13$ and $5.80 \%$, respectively). In addition, the greater development of mammary gland tissue and the synthesis ability of the udder in multiparous ewes could help explain this increase in fat and protein and, therefore, in cheesemaking components. Finally, regarding health of the udder, $\mathrm{CE}$ was significantly higher in milk from ewes with no previous lesions of the udder than in ewes that had suffered udder damage in previous lactations (68.9 vs. $63.8 \%$ ). This could be caused by residual proteolytic activity persisting as a response to a previous udder infection (Caballero-Villalobos et al., 2017).

\section{Implications}

The modeling perspective of the present study applies a methodology widely used in the economic sciences to a biological field (i.e., dairy production). An advantage of this approach is the ability to jointly optimize several variables, which can be easily implemented to improve profitability in both the cheese industry and dairy farms, particularly for breeds such as Manchega, where almost all milk produced is intended for cheesemaking.

Using 1 herd as a single source of animals could be a possible limitation of the model; however, it eliminates the effect of other external factors that might affect CE (such as breeding, nutrition, or management). Furthermore, past improvements on the herd used in our study culminated in the implementation of the Manchega Ovine Breed Selection Scheme, thus the genetically high-quality level of the herd makes it an ideal source for the evaluation of CE in Manchega.

In the last decade, the integration of new herds in the Manchega selection scheme has led to the improvement of sanitary conditions and milk quality in dairy farms, reducing bulk tank SCC and colony-forming units and increasing fat and protein concentration, which has had a positive effect on cheesemaking (Arias et al., 2016). During this time, Manchego cheesemakers also have worked to counteract factors causing inefficiency of the coagulation process. Several techniques, such as the addition of calcium chloride and standardization of $\mathrm{pH}$ with acetic or lactic acid before rennet coagulation, have been proven to cancel out the negative effects of SCC, increasing yields during the cheesemaking process (Caballero Villalobos et al., 2015). Likewise, highpressure treatments have been recently proposed as an alternative to heat-treatments to improve coagulation and milk quality (Kelly and Zeece, 2009). High-pressure treatments have been reported to considerably improve cheesemaking properties of milk by shortening RCT, increasing curd yield, and significantly reducing the activity of indigenous enzymes such as PL (Moatsou et al., 2008). Thus, the use of this technology in Manchega ewe milk is presented as a potential tool to optimize CE and reduce the effect of the inefficiency factors identified in the current study.

\section{CONCLUSIONS}

Curd firmness and RCT can be jointly optimized using the methodological approach of technical efficiency. The average CE in Manchega ewe milk was $68.9 \%$, indicating that there is room for improvement. The factors that explain inefficiency in the coagulation process are, primarily, a higher initial $\mathrm{pH}$ of milk; secondarily, with a moderate effect from lower $\mathrm{CP}$, lower casein, and higher plasmin activity; and, finally, a minor effect from FPD, SCC, colony-forming units, and fat concentration. A significant number of herds still do not participate in the Manchega selection scheme, which should be regarded as a field of work for the improvement of efficiency at farm level. In addition, although cheesemakers currently make use of several methodologies to enhance cheese yield, we believe that new emerging technologies should be considered to optimize $\mathrm{CE}$ and mitigate the effects of factors causing inefficiency. The application of high pressure has not been yet commercially exploited in Manchega ewe milk, but we expect its controlled use should help optimize CE by reducing RCT and also diminishing proteolytic activity in raw milk. This could be implemented as an alternative to heat treatments to preserve milk nutritional value. However, sensorial properties of cheese manufactured under such conditions should be studied in depth to evaluate applicability and fine-tuning of these techniques in the production of Manchego cheese. In addition to our study results, the effect of other factors, such as genetics, nutrition, or flock management, should be considered in further studies.

\section{ACKNOWLEDGMENTS}

This project was funded by the Government of Spain (Ministerio de Educación, Cultura y Deporte/Ministerio de Economía y Competitividad), the industrial partner Agrométodos S.A. (Madrid, Spain), Santander Universidades (Madrid, Spain), and ceiA3 (Campus de Excelencia Internacional Agroalimentario, Cordoba, Spain), through the research program "Doctores en Empresas." 


\section{REFERENCES}

Abilleira, E., M. Virto, A. Nájera, J. Salmerón, M. Albisu, F. J. PérezElortondo, J. C. Ruiz De Gordoa, M. De Renobales, and L. J. R. Barron. 2010. Effects of seasonal changes in feeding management under part-time grazing on the evolution of the composition and coagulation properties of raw milk from ewes. J. Dairy Sci. 93:3902-3909. https://doi.org/10.3168/jds.2009-2983.

Alam, F. 2011. Measuring technical: allocative and cost efficiency of pangas (Pangasius hypophthalmus: Sauvage 1878) fish farmers of Bangladesh. Aquacult. Res. 42:1487-1500. https://doi.org/10 .1111/j.1365-2109.2010.02741.x.

Albenzio, M., and A. Santillo. 2011. Biochemical characteristics of ewe and goat milk: Effect on the quality of dairy products. Small Rumin. Res. 101:33-40. https://doi.org/10.1016/j.smallrumres.2011 .09 .023 .

Albenzio, M., A. Santillo, M. Caroprese, F. D'Angelo, R. Marino, and A. Sevi. 2009. Role of endogenous enzymes in proteolysis of sheep milk. J. Dairy Sci. 92:79-86. https://doi.org/10.3168/jds.2008 -1439 .

Ali, A. K. A., and G. E. Shook. 1980. An optimum transformation for somatic cell concentration in milk. J. Dairy Sci. 63:487-490.

Angón, E., A. García, J. Perea, R. Acero, P. Toro-Mújica, H. Pacheco, and A. González. 2013. Technical efficiency and viability of grazing dairy cattle systems in La Pampa, Argentine. Agrociencia 47:443-456.

Arias, R., R. Gallego, S. Altares, A. Garzón, J. Romero, L. Jiménez, B. Oliete, C. Arias, J. Caballero, A. Martínez, N. Núñez, A. García, M. Ramón, V. Montoro, and M. D. Pérez-Guzmán. 2016. Quality of milk in Manchego sheep flocks. A review. Arch. Zootec. 65:469-473.

Banker, R. D., and R. Natarajan. 2008. Evaluating contextual variables affecting productivity using data envelopment analysis. Oper. Res. 56:48-58. https://doi.org/10.1287/opre.1070.0460.

Bastian, E., and R. Brown. 1996. Plasmin in milk and dairy products: An update. Int. Dairy J. 6:435-457.

Bencini, R. 2002. Factors affecting the clotting properties of sheep milk. J. Sci. Food Agric. 82:705-719. https://doi.org/10.1002/jsfa .1101 .

Bittante, G., M. Penasa, and A. Cecchinato. 2012. Invited review: Genetics and modeling of milk coagulation properties. J. Dairy Sci. 95:6843-6870. https://doi.org/10.3168/jds.2012-5507.

Caballero-Villalobos, J., A. Garzón, A. L. Martínez, R. Arias, F. Ciocia, and P. L. H. McSweeney. 2017. Plasmin activity in Manchega ewe milk: the effect of lactation, parity and health of the udder, and its influence on milk composition and rennet coagulation. Small Rumin. Res. https://doi.org/10.1016/j.smallrumres.2017.10 .005. In press.

Caballero-Villalobos, J., A. Garzón, B. Oliete, R. Arias, L. Jiménez, N. Núñez, and A. Martínez. 2015. Relationship of somatic cell count and composition and coagulation properties of ewe's milk. Mljekarstvo 65:138-143. https://doi.org/10.15567/mljekarstvo .2015 .0208 .

Casado Cimiano, P. 1991. Métodos para el análisis de los principales constituyentes de la leche. Pages 198-199 in Guía para el Análisis Químico de la Leche y los Derivados Lácteos. Ediciones Ayala, Madrid, Spain.

Casper, J. L., W. L. Wendorff, and D. L. Thomas. 1998. Seasonal changes in protein composition of whey from commercial manufacture of caprine and ovine specialty cheeses. J. Dairy Sci. 81:31173122 .

Cinemre, H., V. Ceyhan, M. Bozoglu, K. Demiryürek, and O. Kiliç. 2006. The cost efficiency of trout farms in the Black Sea Region, Turkey. Aquaculture 251:324-332. https://doi.org/10.1016/j .aquaculture.2005.06.016.

De Marchi, M., R. Dal Zotto, M. Cassandro, and G. Bittante. 2007. Milk coagulation ability of five dairy cattle breeds. J. Dairy Sci. 90:3986-3992. https://doi.org/10.3168/jds.2006-627.

García, A., N. Ceular, J. M. Caridad, R. Acero, J. M. Perea, and M. E. Martín. 2007. Determinación de funciones de producción y análisis de eficiencia de la invernada pampeana argentina. Arch. Zootec. 56:23-32.

Greene, W. 1980. On the estimation of a flexible frontier productionmodel. J. Econom. 13:101-115.

Iliyasu, A., and Z. A. Mohamed. 2016. Evaluating contextual factors affecting the technical efficiency of freshwater pond culture systems in Peninsular Malaysia: A two-stage DEA approach. Aquacult. Rep. 3:12-17. https://doi.org/10.1016/j.aqrep.2015.11.002.

Ismail, B., and S. Nielsen. 2010. Invited review: Plasmin protease in milk. current knowledge and relevance to dairy industry. J. Dairy Sci. 93:4999-5009. https://doi.org/10.3168/jds.2010-3122.

Jaramillo, D., A. Zamora, B. Guamis, M. Rodríguez, and A. J. Trujillo. 2008. Cheesemaking aptitude of two Spanish dairy ewe breeds: changes during lactation and relationship between physico-chemical and technological properties. Small Rumin. Res. 78:48-55. https://doi.org/10.1016/j.smallrumres.2008.04.005.

Kaliba, A. R., and C. R. Engle. 2006. Productive efficiency of catfish farms in Chicot County: Arkansas. Aquac. Econ. Manag. 10:223243. https://doi.org/10.1080/13657300600985413.

Kelly, A. L., and M. Zeece. 2009. Applications of novel technologies in processing of functional foods. Aust. J. Dairy Technol. 64:12-15.

Koutsouli, P., G. Patounasa, T. Massourasb, I. Bizelisa, and I. Politis. 2015. Plasmin-plasminogen system and milk coagulation properties of two Greek dairy sheep breeds. Small Rumin. Res. 124:89 94. https://doi.org/10.1016/j.smallrumres.2015.01.015.

Leitner, G., N. Silanikove, and U. Merin. 2008. Estimate of milk curd yield of sheep and goats with intramammary infection and its relation to somatic cell count. Small Rumin. Res. 74:221-225. https:// doi.org/10.1016/j.smallrumres.2007.02.009.

Logan, A., L. Day, A. Pin, M. Auldist, A. Leis, A. Puvanenthiran, and M. A. Augustin. 2014. Interactive effects of milk fat globule and casein micelle size on the renneting properties of milk. Food Bioprocess Technol. 7:3175-3185. https://doi.org/10.1007/s11947 $-014-1362-2$

Lucey, J. A., and P. F. Fox. 1992. Rennet coagulation properties of late-lactation milk: Effect of $\mathrm{pH}$ adjustment, addition of $\mathrm{CaCl}_{2}$, variation in rennet level and blending with mid-lactation milk. Ir. J. Agric. Food Res. 31:173-184.

Manca, M. G., J. Serdino, G. Gaspa, P. Urgeghe, I. Ibba, M. Contu, P. Fresi, and N. P. P. Macciotta. 2016. Derivation of multivariate indices of milk composition, coagulation properties, and individual cheese yield in dairy sheep. J. Dairy Sci. 99:4547-4557. https://doi .org/10.3168/jds.2015-10589.

McDonald, J. 2009. Using least squares and tobit in second stage DEA efficiency analyses. Eur. J. Oper. Res. 197:792-798. https://doi .org/10.1016/j.ejor.2008.07.039.

McMahon, D., and R. Brown. 1982. Evaluation of Formagraph for comparing rennet solutions. J. Dairy Sci. 65:1639-1642.

Moatsou, G. 2010. Indigenous enzymatic activities in ovine and caprine milks. Int. J. Dairy Technol. 63:16-31. https://doi.org/10 .1111/j.1471-0307.2009.00552.x.

Moatsou, G., C. Bakopanos, D. Katharios, G. Katsaros, I. Kandarakis, P. Taoukis, and I. Politis. 2008. Effect of high-pressure treatment at various temperatures on indigenous proteolytic enzymes and whey protein denaturation in bovine milk. J. Dairy Res. 75:262269. https://doi.org/10.1017/S002202990800321X.

Morantes, M., R. Dios-Palomares, M. E. Peña, J. Rivas, J. Perea, and A. García-Martínez. 2017. Management and productivity of dairy sheep production systems in Castilla-La Mancha, Spain. Small Rumin. Res. 149:62-72. https://doi.org/10.1016/j.smallrumres.2017 .01 .005 .

Pazzola, M., F. Balia, V. Carcangiu, M. L. Dettori, G. Piras, and G. M. Vacca. 2012. Higher somatic cells counted by the electronic counter method do not influence renneting properties of goat milk. Small Rumin. Res. 102:32-36. https://doi.org/10.1016/j .smallrumres.2011.08.005.

Pazzola, M., M. L. Dettori, C. Cipolat-Gotet, A. Cecchinato, G. Bittante, and G. M. Vacca. 2014. Phenotypic factors affecting coagulation properties of milk from Sarda ewes. J. Dairy Sci. 97:72477257. https://doi.org/10.3168/jds.2014-8138. 
Pérez, J., J. M. Gil, and I. Sierra. 2007. Technical efficiency of meat sheep production systems in Spain. Small Rumin. Res. 69:237-241. https://doi.org/10.1016/j.smallrumres.2006.02.003.

Pirisi, A., G. Piredda, M. Corona, M. Pes, S. Pintus, and A. Ledda. 2000. Influence of somatic cell count on ewe's milk composition, cheese yield and cheese quality. Pages 47-59 in 6th Great Lake Dairy Sheep Symposium. Guelph, Ontario, Canada. University of Wisconsin-Madison, WI.

Pulido, A., and J. Pérez. 2001. Modelos Econométricos: Guía para la Elaboración de Modelos Econométricos con EViews. Pirámide, Madrid, Spain.

Raynal-Ljutovac, K., P. Gaborit, and A. Lauret. 2005. The relationship between quality criteria of goat milk, its technological properties and the quality of the final products. Small Rumin. Res. 60:167-177. https://doi.org/10.1016/j.smallrumres.2005.06.010.

Richardson, B., and K. Pierce. 1981. The determination of plasmin in dairy products. N. Z. J. Dairy Sci. 16:209-220.

Rivas, J., J. Perea, E. Angón, C. Barba, M. Morantes, R. DiosPalomares, and A. García. 2015. Diversity in the dry land mixed system and viability of dairy sheep farming. Ital. J. Anim. Sci. 14:179-186. https://doi.org/10.4081/ijas.2015.3513.
Sevi, A., M. Albenzio, R. Marino, A. Santillo, and A. Muscio. 2004 Effects of lambing season and stage of lactation on ewe milk quality. Small Rumin. Res. 51:251-259. https://doi.org/10.1016/S0921 $-4488(03) 00196-2$.

Sturaro, A., M. Penasa, M. Cassandro, A. Varotto, and M. De Marchi. 2014. Effect of microparticulated whey proteins on milk coagulation properties. J. Dairy Sci. 97:6729-6736. https://doi.org/10 $.3168 /$ jds.2014-8157.

Theodorou, G., A. Kominakis, E. Rogdakis, and I. Politis. 2007. Factors affecting the plasmin-plasminogen system in milk obtained from three Greek dairy sheep breeds with major differences in milk production capacity. J. Dairy Sci. 90:3263-3269. https://doi.org/ 10.3168/jds.2006-780.

Timmer, C. 1971. Using a probabilistic frontier production function to measure technical efficiency. J. Polit. Econ. 79:776-794

Toro-Mújica, P., A. García, G. Gómez-Castro, R. Acero, J. Perea, V. Rodríguez-Estévez, C. Aguilar, and R. Vera. 2011. Technical efficiency and viability of organic farming dairy sheep in a traditional area for sheep production in Spain. Small Rumin. Res. 100:89-95. https://doi.org/10.1016/j.smallrumres.2011.06.008. 